\title{
FACTORS THAT INFLUENCE ALLOCATION OF EMPLOYEE TIME TOWARDS PALM OIL PRODUCTIVITY FOR PLASMA FARMING IN THE DISTRICT OF MUSI BANYUASIN
}

\author{
Lifianthi*, Oktarina Selly, Rosana Elly, Sari Dwi Wulan \\ Faculty of Agriculture, University of Sriwijaya, Indonesia \\ *E-mail: llifianthi@yahoo.co.id
}

\begin{abstract}
This study examines how plasma farmers allocate working time for oil palm activities, activities outside of oil palm and non-farm activities, and factors affecting the time allocation of oil palm farmers. South Sumatera, especially Musi Banyuasin Regency, has potential in the development of oil palm plantations. Oil palm is a cultivation plant whose maintenance is relatively easy, which induces farmers who are working with more than palm oil to increase their household income. In the case of palm oil farming development, oil palm farming activities are supported also with natural resources and oil palm crops can develop on land that has a diverse agricultural ecosystem. Oil palm farmers in this study were plasma farmers (farmers working with corporations as the core). The non-farming time allocation for palm oil is greater than the allocation of working time in oil palm farming. Factors influencing the allocation of working time of palm oil growers are influenced by income and age.
\end{abstract}

\section{KEYWORDS}

Allocation, working time, productivity, farmers.

The price fluctuations for fresh fruit bunch (TBS) as well as changes in production and product price can be drivers of technological innovation in production; such innovation is undertaken to increase the efficiency of production factor use and/or increase crop productivity, in order to obtain maximum income while ensuring farmer income stability. Meanwhile, income derived from palm oil farming, non-palm oil farming, and outside palm farming is used to meet family needs, consisting of food and non-food consumption expenditures (Mingorria et al., 2014).

When linking the increase in the productivity of palm oil plantations with the use of factors of production conducted by smallholders, it can be seen how the use of production factors is used in the business activities undertaken by palm oil growers and how much profit is realized by each farmer conducting palm oil farming activities.

Musi Banyuasin Regency is one of the districts in South Sumatera Province, which has potential for the development of palm oil farming. Given a large number of household economies that depend on palm oil plantations, these conditions are attractive and relevant for a deeper review of how palm oil plantations are managed by smallholders, where household members in a farm household usually work together in a farming activity. In relation to the prospect and potential, there is an increasing number of farmers who rely on this commodity plantation, namely plasma farmers, as one of the main sources of livelihood for the fulfilment of life needs, in addition to other plantation crops such as rubber, coffee, and tea.

Lifianthi and Husin (2012), revealed that labor productivity can provide very high income when compared with other productive activities. However, plasma farmers are not so serious in managing their oil palm plantations. Farmers apparently work in oil palm farming as managers.

The amount of time allocated by family members in the farming activities is determined by the number of productive assets owned, such as land area or other productive capital. The greater the asset, the greater the number of working hours agreed to by the household members. Activities that absorb labour include fertilizing, weeding, and harvesting. In their free time, many household members allocate time for productive activities both in agricultural and other sectors that can provide additional family income (Fahmi, 2009; Hunt, 2000). 
According to Utami (2011), the factors that affect the workforce are the total allocation of work time and the family workforce. If the total allocation of labour time on farming is less, family members will spend more time on other activities. Thus, the allocation of working time outside of farming is negatively related to the allocation of labour time in other activities.

Based on this fact, the authors are interested in examining the allocation of household working time of palm oil (plasma farmers) and the factors that affect the allocation of working time.

\section{METHODS OF RESEARCH}

The sampling technique used was proportioned stratified random sampling, using a sample of 30 farmers. Sampling by only a few members of the population will represent the palm oil farmers in the village of Berlin Makmur in the Musi Banyuasin Regency. To reach our research objectives, we used a mathematical operational model that will be described in detail for each objective.

To determine the plasma worker's time allocation by calculating farmers' working time allocation from the household activity of the palm oil plantation and other activities, the mathematical calculation is as follows:

$$
\begin{aligned}
& \text { Total } \mathrm{JK}=\mathrm{JO} \times \mathrm{HK} \times \mathrm{JK} \\
& H O K=\frac{J K \text { Total }}{J K S}
\end{aligned}
$$

Where: $\mathrm{HOK}=$ working day, $\mathrm{JO}=$ number of people, $\mathrm{HK}=$ day of work (Day), JK = working hours, and JKS $=$ standard working hours $(7$ hours for farming and 8 hours exclusive of farming) (Department of Manpower and Transmigration, 2007).

To analyse the existence of other working time allocation factors, the number of family members, education, age, land area, and income from palm oil farming and other activities on farmer work time allocation was used for multiple linear regression equations, with the equation as follows (Gujarati, 2006):

$$
\operatorname{LnY}_{1 \text { (plasma) }}=\operatorname{Lnb}_{01}+b_{11} \operatorname{LnX} X_{11}+b_{21} L n X_{21}+b_{31} L n X_{31}+b_{41} L n X_{41}+b_{51} L n X_{51}+b_{61} \operatorname{LnX} X_{61}+b_{71} \operatorname{LnX} X_{71}+e(3)
$$

Where: $\mathrm{Y} 1$ = allocation of working time of palm oil farming farmer $(\mathrm{HOK})$; b01 = allocation of working time of palm oil farmers at other time of work allocation, number of family members, age, education, land area, and income of palm oil farming and other activity income equal to zero; X11 = allocation of other working time (HOK/year); X21 = number of family members (person); X31 = age (year); X41 = education (year); X51 = land area (ha); X61 = palm oil farming income (Rp/year); $X 71=$ revenue other than palm oil $(\mathrm{Rp} / \mathrm{year}) ; \mathrm{e}=$ interference variable.

Hypothesis testing was done to understand the effect of observed variables on the allocation of working time for palm oil. This test was done by using the $F$ test, with the formula as:

$$
\mathrm{F}_{\text {count }}=\frac{\mathrm{R}^{2} /(\mathrm{k}-1)}{\left(1-\mathrm{R}^{2}\right) /(\mathrm{n}-\mathrm{k})}
$$

Where: $\mathrm{k}=$ number of parameters and $\mathrm{n}=$ number of samples.

Decision rule:

- If Fcount $<$ Ftable $(\alpha=0.10)$, then accept Ho, meaning that the independent variable has no significant effect on the dependent variable;

- If Fcount $>$ Ftable $(\alpha=0.10)$, then reject Ho, meaning that the independent variables significantly affect the independent variable.

While the influence of each independent variable on the dependent variable was determined by (partially) using the t-test, as follows: 


$$
t_{\text {count }}=\frac{b_{i}}{\operatorname{Se}\left(b_{i}\right)}
$$

Where: $\mathrm{bi}=$ partial regression coefficient and Se $(\mathrm{bi})=$ standard error .

Rules of decision:

- If $t$-count $<t$-table $(\alpha=0.10)$, accept $\mathrm{Ho}$, meaning that the independent variables have no significant effect on the dependent variable;

- If $\mathrm{t}$-count $>\mathrm{t}$-table $(\alpha=0.10)$, reject Ho, meaning that the independent variables significantly affect the dependent variable.

\section{RESULTS AND DISCUSSION}

Analysis of Plasma Farmers' Work Time Allocation. The main farming activity was done by plasma farmers in the village of Berlian Makmur. Most of the farmers have 2 hectares of palm oil plantation. Farming activities begin from planting until harvesting. The activities including fertilizing, pest and plant disease management, cutting, and harvesting. These activities are done to provide best results from palm TBS production, especially given the age of palm oil trees in this study, which is between 16 and 20 years old.

In this study, farmers that are implementing these activities are using family workers such as the husband, wife, and children. Some farmers also are using hired workers when their own age has become a factor or they do not have enough family labour. Averages for working time allocation of inside and outside palm oil farmers can be seen in Table 1.

Table 1 - Average Working Time per Year, Family Members and Non-Family Members, for Palm Oil (Plasma) Farmers

\begin{tabular}{|c|c|c|c|}
\hline & Individuals & Work Time Allocation & Percentage $(\%)$ \\
\hline \multicolumn{4}{|c|}{ a. HOK Family Members } \\
\hline 1. & Male & 3.22 & 56.19 \\
\hline 2. & Female & 1.38 & 24.09 \\
\hline & Child & 1.13 & 19.72 \\
\hline Tot & & 5.73 & 100.00 \\
\hline \multicolumn{4}{|c|}{ b. HOK Non-Family Members } \\
\hline 1. & Male & 58.17 & 86.06 \\
\hline $\begin{array}{l}2 . \\
3 .\end{array}$ & $\begin{array}{l}\text { Female } \\
\text { Child }\end{array}$ & $\begin{array}{l}9.42 \\
0.00\end{array}$ & $\begin{array}{l}13.94 \\
0.00\end{array}$ \\
\hline Tot & & 67.59 & 100.00 \\
\hline
\end{tabular}

Based on Table 1, palm oil (plasma) farmers prefer to use non-family workers. Utilization of outside workers (hired workers) was $67.59 \mathrm{HOK}$ on average per year. This labour was used for four activities (fertilizer application, pest and plant disease control, cutting, and harvesting), which was mostly done by adult males-58.17 HOK per year, compared with adult females-9.42 HOK per year. Female labor is as a worker assisting men's work in maintenance activities (such as fertilizing and controlling plant pests and diseases). This is expressed also by (Ellis, 1988) that female labor (wife), usually they work not only to assist the work of the husband, but also to participate in productive economic activities.

It is also revealed by Zahri (2005) that farmers who have the main business of oil palm allocate manpower to manage oil palm plantations very little and can be categorized as the occurrence of underemployment rate (available hours are not used optimally for activities). For harvesting all the plasma farmer activities were done using non-family labourers. This is because palm oil fruits must be quickly processed at the factory. Delays in the harvest process will cause palm oil fruits to become acidic so that they can no longer be processed. In addition, from this sample of plasma farmers, almost all preferred to use outside workers rather than family workers.

Lifianthi, et al (2014), stated that there is still a lot of free time that can be utilized by oil palm farmers. Therefore, farmers should seek employment outside of productive palm oil 
farming and can contribute income to their households. There is still time to spare (from the potential of existing working days per year) which amounted to 359.93 working days.

The palm oil (plasma) farmer is doing other farming besides palm oil. Rubber is another commodity that farmers have, and it also requires both family and non-family labour. Farm activities involved with rubber plantations are similar to those of palm oil. These activities include fertilizing, pest and plant disease control, land cleaning, tapping, and production management after harvesting (coagulation of latex), which reaches $344.35 \mathrm{HOK}$ per ha per year. Averages for time allocation can be seen in Table 2.

Time allocation is dominated by the head of family (husband), for which the average was 203.29 HOK per year compared with only 136.16 HOK on average for women and 4.90 HOK on average for children. This time was allocated mostly in tapping because it was done every day. This activity is also useful to maximize time allocation during waiting times in palm oil production. Governmental and other research has shown rubber tapping to be once every two days. In contrast, farmers are doing this every day because during the rainy season tapping is interrupted, and farmers try to prevent the mixing of rainfall and rubber latex, which can lead to reduced quality. Use of non-family workers for rubber farming averages 4.95 HOK per year.

Table 2 - Average Working Time per Year, Family Members and Non-Family Members, for Palm Oil (Plasma) Farmer Families in Rubber Farming

\begin{tabular}{llll}
\hline No. & Individuals & Work Time Allocation & Percentage $(\%)$ \\
\hline a. HOK Family & Members & \\
1. & Male & 203.29 & 59.04 \\
2. & Female & 136.16 & 39.54 \\
3. & Child & 4.90 & 1.42 \\
\hline Total & & 344.35 & 100.00 \\
\hline b. HOK Non-Family Members & & \\
1. & Male & 4.95 & 100.00 \\
2. & Female & 0.00 & 0.00 \\
3. & Child & 0.00 & 0.00 \\
\hline Total & & 4.95 & 100.00 \\
\hline
\end{tabular}

Palm oil (plasma) farmers also utilize their time with other productive activities. The total time allocation for these other activities is 134.22 HOK on average per year. Such activities are undertaken to increase total income and consist of small shop and electric shop work, portage, wood craftsmanship, truck driving, public transport driving, tailoring, midwifery, and others.

Table 3 - Average Working Time per Year of Plasma Farmers in Non-Farming Activities

\begin{tabular}{llll}
\hline No. & Individuals & Work Time Allocation & Percentage (\%) \\
\hline 1. & Men & 86.54 & 64.48 \\
2. & Women & 47.68 & 35.52 \\
\hline Total & & 134.22 & 100.00 \\
\hline
\end{tabular}

Analysis of Influencing Factors of Work Time Allocation for Plasma Farmers. Factors that influence the working time allocation of farmers are working time allocation for rubber farming, working time allocation for non-farming activities, number of family members, age of the farmer, education, palm oil income, rubber income, and non-farming income. Because of a regression analysis, re-specification of the equation model yielded the desired results according to sign and could be economically analysed.

The multiple linear regression analysis used working time allocation in plasma farming activities as the dependent variable, and the independent variables were working time allocation in rubber farming, working time allocation in non-farming, number of family members, age of family head, education, palm oil income, rubber income, and non-farming income, as seen in Table 4.

Based on the regression analysis, two independent variables were found to have a significant influence: work time allocation for rubber farming and education. For working time 
allocation in non-farming activities, the number of family members, age of farmer, palm oil income, rubber income, and non-farming income were not significantly influential.

In addition, the determination of coefficient value $\left(R^{2}\right)$ was 32.90 percent or 0.329 , which means that 32.90 percent of the variation of factors influencing working time allocation in farmer activity could be explained by the variables, while the remaining 67.10 percent could be explained by other variables that were not included in the equation.

Table 4 - Factors Influencing Plasma Farmer Work Time Allocation

\begin{tabular}{llll}
\hline Variable & Parameter Value & t-statistic & significant \\
\hline (Constant) & 1.432 & 0.178 & 0.861 \\
HOK Rubber (X1) & 0.288 & 1.174 & $0.253^{* *}$ \\
HOK No Farming (X2) & 0.000 & -0.005 & 0.996 \\
Number of Family Members (X3) & -0.074 & -0.337 & 0.740 \\
Age of Farmer (X4) & 0.093 & 0.501 & 0.621 \\
Education (X5) & 0.335 & 2.640 & $0.015^{\star * \star *}$ \\
Income from Palm Farming (X6) & 0.067 & 0.216 & 0.831 \\
Income from Rubber Farming (X7) & -0.098 & -0.366 & 0.718 \\
Income from Non-Farming (X8) & 0.043 & 0.894 & 0.382 \\
\hline R-Square & 0.329 & & \\
F Statistic & 1.285 & & \\
Durbin-Watson & 2.243 & & \\
\hline
\end{tabular}

Note: ${ }^{* * \star}=$ Significant in $\alpha=0.15 ;{ }^{* \star}=$ Significant in $\alpha=0.20$.

The work time allocation variable in rubber farming shows this variable to have tangible influence on work time allocation in palm farming activities. The result showed that the regression coefficient of working time allocation in rubber farming was 0.288 , which means that a 1 percent increase in working time allocation for rubber farming would lead to increasing working time allocation in palm farming in the amount of 0.288 percent. Working time allocation in rubber farming had a tangible influence on working time allocation in palm oil farming activity. This is because with an increase in work time allocation for rubber farming, farmers will allocate time owned for palm oil farming, particularly time allocation for fertilizer application, weed control, and maintenance.

Farmers will continue these activities because they are certain to contribute to the family income. Thus, farmers will consistently allocate their working time to activities such as harvesting, and they will then try to find the additional time for non-farming activities.

The education variable for the head of family shows that the regression coefficient of education is 0.335 , which means that a 1 percent increase in the plasma farmer's education will increase the work time allocation in palm farming by 0.355 percent. This shows that the education variable of the plasma farmer family head has tangible influence toward the working time allocation variable in palm farming activities. The higher the plasma farmer's education, the more intensive and selective will be the work time allocation in palm farming activities.

By utilizing working time allocation in their palm farming for maintenance activities, plasma farmers could increase the productivity of TBS. The education level of plasma farmers has tangible influence on land management and cultivation, and thus plasma farmers could expect to obtain a profit from their farming.

\section{CONCLUSION AND SUGGESTIONS}

In addition to oil palm farming, plasma farmers also allocate working time to conduct rubber farming activities. Farmers still have spare time, because the activities of oil palm farming do not require intensive care. The dominant activity undertaken besides farming is traders. Significant factors in the allocation of working time of plasma farmers are rubber work leisure time and education level.

The advice given that the plasma farmers have the potential to conduct oil palm farming properly, so they need guidance in cultivation activities. The allocation of working 
time is still low for farming activities, but the available resources have great potential if properly managed so as to provide additional benefits to farmers.

\section{REFERENCES}

1. Dinas Ketenagakerjaan dan Transmigrasi, 2007. Jam Kerja Standar Usahatani. Jakarta, Indonesia.

2. Ellis, F. 1988. Peasant Economics: Farm Households and Agrarian Development. Cambridge University Press. Cambridge.

3. Fahmi, N.F. Analisis Curahan Kerja Rumahtangga Petani Lahan Sawah Di Kabupaten Donggala Sulawesi Tengah. Jurnal Sosial Ekonomi Pertanian. Institut Pertanian Bogor. http://repository.ipb.ac.id (accessed on October 25th, 2016).

4. Gujarati, D.N. 2006. Dasar-Dasar Ekonometrika Jilid 1, Penerbit Erlangga. Jakarta.

5. Hunt, R. C. 2000. Labor Productivity and Agricultural Development: Boserup Revisited. Hum. Ecology. 28 (2): 251 - 276. Spriger (accessed on September 28th, 2016).

6. Lifianthi dan Husin, L. 2012. Productivity and Income Performance Comparison of Smallholder Oil Palm Plantation at Dry Land and Wet Land of South Sumatera Indonesia. APCBEE Procedia 3, $270-275$.

7. Lifianthi, S. Oktarina, dan D. Aryani. 2014. Perbandingan Kontribusi Pendapatan Dan Pengeluaran Konsumsi Petani Plasma Kelapa Sawit di Dua Tipologi Lahan di Sumatera Selatan. Jurnal [Internet]. Indralaya. (http://www.pur-plso-unsri.org.), (accessed on April 6th, 2016).

8. Mingorria, S., Gamboa, G., Lopez, B. M and Corbera, E. 2014. The Oil Palm Boom: Socio-Economic Implications for Q'eqchi' Households in The Polochic Valley, Guatemala. Environ. Dev. Sustain. 16 (4): 1 - 31. Springer (accessed on September 13th, 2016).

9. Suratiyah, 2008. Ilmu Usahatani. Edisi Revisi. Penebar Swadaya. Jakarta, Indonesia.

10. Utami, D.C. 2011. Analisis Diversifikasi Pendapatan dan Transmisi Harga Tandan Buah Segar (TBS) Kelapa Sawit pada Petani Swadaya di Desa Sari Galuh Kecamatan Tapun Kabupaten Kampar. Agriculture Faculty, Riau University. Riau, Indonesia.

11. Zahri, I. 2005. Determinan dan Dampak Alokasi Tenaga Kerja Keluarga pada Kegiatan Produktif Terhadap Pendapatan Petani Plasma PIR Kelapa Sawit Sumatera Selatan. Jurnal Agribisnis dan Industri Pertanian. Vol.4 (2) pg. 63 -68. 